\title{
47. CHERT AND PORCELLANITE FROM DEEP SEA DRILLING PROJECT SITE 436, NORTHWEST PACIFIC
}

\author{
K. A. Pisciotto, ${ }^{1}$ Earth Science Board, University of California, Santa Cruz, California
}

\begin{abstract}
Cretaceous chert and porcellanite recovered at Site 436, east of northern Honshu, Japan, are texturally and mineralogically similar to siliceous rocks of comparable age at Sites 303, 304, and 307 in the northwest Pacific. These rocks probably were formed by impregnation of the associated pelagic clay with locally derived silica from biogenic and perhaps some volcanic debris. Fine horizontal laminations are the only primary sedimentary structures, suggesting minimal reworking and transport. Collapse breccias and incipient chert nodules are diagenetic features related to silicification and compaction of the original sediment.

Disordered opal-CT $(d[101]=4.09 \AA)$ and microgranular quartz (crystallinity index $<1.0$ ) are the two common silica minerals present. Some samples show quartz replacing this poorly ordered opal$\mathrm{CT}$, supporting the notion that opal-CT does not become completely ordered (i.e., $d[101]=4.04 \AA$ ) in some cases before being converted to quartz. The present temperature calculated for the depth of the shallowest chert and porcellanite at this site is $30^{\circ} \mathrm{C}$; this may represent the temperature of conversion of opal-CT to quartz. High reflection coefficients $(0.29-0.65)$ calculated for the boundary between chert-porcellanite and clay-claystone support the common observation that chert is a strong seismic reflector in deep-sea sedimentary sections.
\end{abstract}

\section{INTRODUCTION}

Keene's $(1975,1976)$ comprehensive work on cherts and porcellanites from the North Pacific clearly demonstrates their widespread occurrence and diagenetic origin. At Site 436 of Deep Sea Drilling Project Leg 56, east of northern Honshu, Japan (Figure 1), we recovered only 0.5 meter of Cretaceous bedded chert and porcellanite from sub-bottom depths of 379 to 389 meters; these rocks are very similar to those described by Keene from nearby areas of Sites 303, 304, and 307 (Leg 32). These rocks occur near the base of a sedimentary sequence that includes a condensed section of Cretaceous and Paleogene(?) iron- and manganese-rich clays and superjacent, perhaps unconformably overlying, Neogene deposits comprising radiolarian and diatom ooze and mud (Figure 2). Lancelot and Larson's (1975) paleotectonic reconstructions suggest that these Cretaceous siliceous rocks are the diagenetic products of radiolarian ooze which was deposited below the calcium-carbonate-compensation depth after these sites had migrated north of the equatorial zone of high productivity.

1 Present address: Scripps Institution of Oceanography, Deep Sea Drilling Project, A-031, La Jolla, CA. 92039.
This paper discusses the petrology and origin of cherts and porcellanites at Site 436. In addition, the temperature of formation and acoustic impedances of these siliceous rocks are calculated.

The nomenclature used in this report follows that of Bramlette (1946), Jones and Segnit (1971), and Keene (1975, p. 430). Mineralogical terms for the various polymorphs of silica are opal-A, opal-CT, quartz, and chalcedony.

Chert is herein defined as a hard, conchoidally fracturing, cryptocrystalline, varicolored sedimentary rock with semivitreous, vitreous, or waxy luster, consisting dominantly of silica.

Porcellanite is herein defined as a siliceous sedimentary rock with a dull or mat luster resembling that of unglazed porcelain. It is less hard, dense, and vitreous than chert and commonly has a lower silica content.

Bramlette (1947) emphasized that the various siliceous rocks of the Monterey Shale of California represent a truly gradational series, from essentially unaltered diatomites and diatomaceous mudstones to their diagenetic products: chert, porcellanite, porcellaneous mudstones, and siliceous shales. Consequently, any classification is somewhat arbitrary. Nevertheless, the terms chert and porcellanite, as defined above, adequately describe the Cretaceous siliceous rocks recovered at Site 436. Texture and lithology must not be confused with miner- 


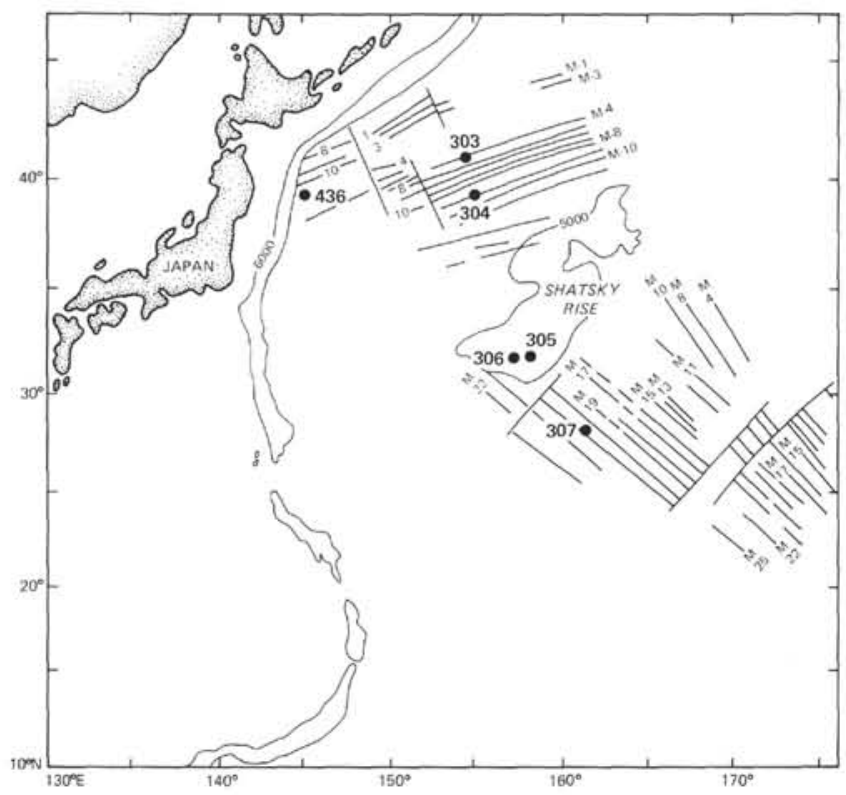

Figure 1. Location of Site 436 (Leg 56). Nearby sites of Leg 32 and magnetic lineations are also shown. (After Keene, 1975, fig. 1.)
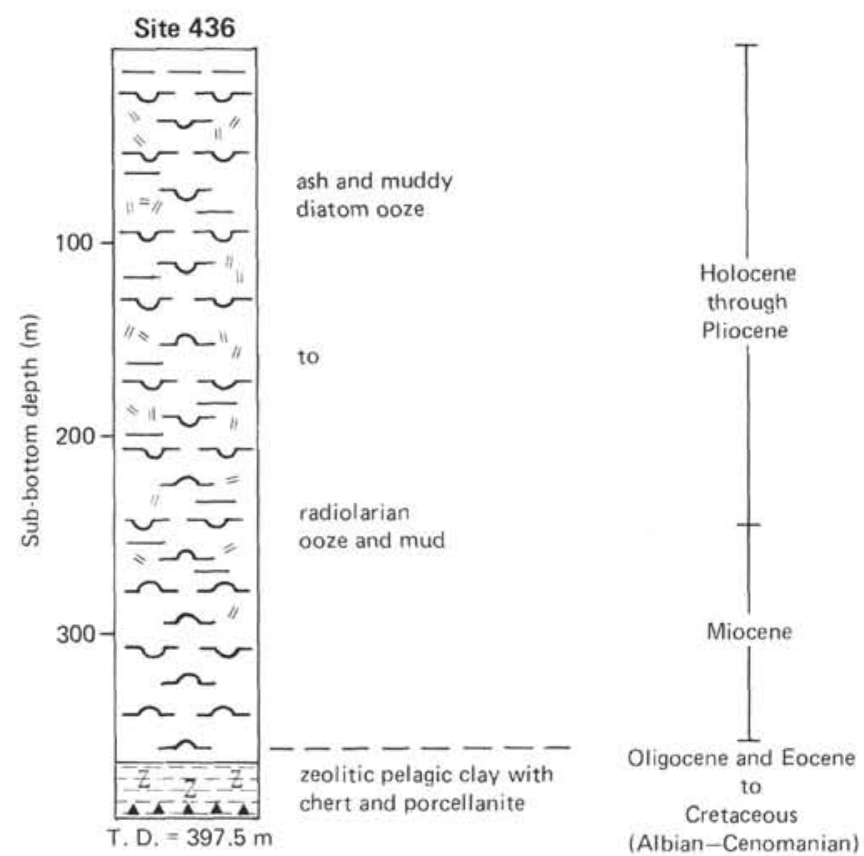

Figure 2. Generalized stratigraphic column, Site 436.

alogy, because cherts and porcellanites may contain opal-CT and (or) quartz and chalcedony.

\section{METHODS}

The materials and analytical techniques used in this study to provide basic textural and mineralogical data include polished slabs of whole rocks, smear slides, thin sections, X-ray diffraction (XRD), and scanning electron microscopy (SEM). For those samples containing opal-CT, I determined the $d(101)$ spacing in the manner of Murata and Larson (1975). Where significant quartz occurs, I calculated values for the crystallinity index (Murata and Norman, 1976) using a scaling factor of 1.36. The relative weight percentages of opal-CT and quartz for samples containing both polymorphs were measured using a determinative curve constructed from XRD traces of known mixtures of opal-CT $(d[101]=$ $4.115 \AA$ ) and diagenetic quartz (crystallinity index = 1.3) taken from the Monterey Shale. The range of uncertainty of these values is $\pm 5 \%$.

I heated all samples for 24 hours at $100^{\circ} \mathrm{C}$ to remove adsorbed water and determined their dry-bulk density using a mercury pycnometer to measure volumes. To estimate porosities and water-saturated-bulk densities I first calculated grain densities, using the maximum and minimum values given by Keene $(1975$, p. 440 , table 2$)$ for samples containing predominantly quartz and opalCT respectively, then adjusted these values for the relative weight percentages of opal-CT and quartz in my samples. The acoustic impedance for each sample is the product of the saturated-bulk density and the measured velocity (Carson and Bruns, this volume).

\section{DESCRIPTIONS OF SILICEOUS ROCKS}

The Cretaceous siliceous rocks recovered at Site 436 are similar in almost every aspect to the noncalcareous cherts and porcellanites described by Keene from Leg 32. (See descriptions of similar rocks from the Pacific basin in Pimm et al., 1971, Sites 45, 46, 50, 52, 59; Heath and Moberly, 1971, Sites 61, 65, 66, 67; Heath, 1973, Site 163; Lancelot, 1973, Sites 164, 166, 168.) Table 1 summarizes the lithologic, mineralogic and physical-property data for these rocks. More-detailed descriptions follow.

\section{Bedding and Structures}

Most of the brown cherts and porcellanites contain recognizable bedding, consisting of alternating light and dark laminations (Figure 3), whereas only indistinct laminations occur in the yellow cherts and pale-brownish-white porcellanite. The microcrystalline-quartz- and chalcedony-filled radiolarian molds that make up many of the lighter colored laminations may be redeposited (Figure 3B). The sharp contact between a quartzosechert bed and the underlying clay-rich radiolarian chert in Sample 436-41-1, 42-43 cm may have been caused by slight or mild reworking of the sediments before burial and lithification (Figure 4).

Light-orange, montmorillonite-rich lenses occurring sporadically in the unsilicified iron- and manganese-rich clays in Cores $436-39$ to $436-40$ may be patches of altered volcanic ash (Larson, Moberly, et al., 1975, p. 48). Orange and red patches now composed of both opal-CT and microcrystalline quartz also exist in several samples of the underlying brown porcellanite and chert (Figure 5). Similar Cretaceous iron- and manganese-rich claystones (umbers), which contain thin, light-colored layers of volcanic ash and are associated with radiolarites and radiolarian mudstones, overly altered pillow basalts on Cyprus (Robertson and Hudson, 1974). 
TABLE 1

Lithology, Mineralogy, and Physical Properties of Cretaceous Cherts and Porcellanites, Site 436

\begin{tabular}{|c|c|c|c|c|c|c|c|c|c|c|c|c|}
\hline $\begin{array}{c}\text { Sample } \\
\text { (interval in } \mathrm{cm} \text { ) }\end{array}$ & $\begin{array}{l}\text { Sub-Bottom } \\
\text { Depth } \\
\text { (m) }\end{array}$ & Lithology & $\begin{array}{c}\text { Silica } \\
\text { Mineralogy }\end{array}$ & $\begin{array}{c}d(101) \\
\text { of Opal-CT } \\
\text { (A) }\end{array}$ & $\begin{array}{l}\text { Crystallinity } \\
\text { of Quartz }\end{array}$ & $\begin{array}{c}\text { Dry-Bulk } \\
\text { Density } \\
\left(\mathrm{g} / \mathrm{cm}^{3}\right)\end{array}$ & $\begin{array}{c}\text { Assumed } \\
\text { Grain Density } \\
\left(\mathrm{g} / \mathrm{cm}^{3}\right)\end{array}$ & $\begin{array}{l}\text { Calculated } \\
\text { Porosity } \\
(\%)\end{array}$ & $\begin{array}{l}\text { Saturated- } \\
\text { Bulk Density } \\
\left(\mathrm{g} / \mathrm{cm}^{3}\right)\end{array}$ & $\begin{array}{c}\text { Measured } \\
\text { Velocity } \\
(\mathrm{km} / \mathrm{s})\end{array}$ & $\begin{array}{c}\text { Acoustic } \\
\text { Impedance } \\
\left(10^{5} \mathrm{~g} / \mathrm{cm}^{2}-\mathrm{s}\right)\end{array}$ & $\begin{array}{c}\text { Associated } \\
\text { Sediment }\end{array}$ \\
\hline $436-41-1,35-37$ & 378.9 & $\begin{array}{l}\text { Brecciated } \\
\text { yellow chert }\end{array}$ & quartz & - & $<1$ & 2.49 & 2.60 & $<4$ & 2.53 & - & - & $\begin{array}{l}\text { Yellow and brown } \\
\text { zeolitic clay }\end{array}$ \\
\hline $436-41-1,40-42$ & 378.9 & $\begin{array}{l}\text { Pale brownish- } \\
\text { white porcel- } \\
\text { lanite }\end{array}$ & quartz & - & $<1$ & 1.65 & 2.60 & 37 & 2.29 & - & - & $\begin{array}{l}\text { Yellow and brown } \\
\text { zeolitic clay }\end{array}$ \\
\hline $436-41-1,42-44$ & 378.9 & $\begin{array}{l}\text { Brecciated } \\
\text { yellow chert }\end{array}$ & quartz & - & 1.1 & 2.50 & 2.60 & $<4$ & 2.54 & 4.1 & 10.5 & $\begin{array}{l}\text { Yellow and brown } \\
\text { zeolitic clay }\end{array}$ \\
\hline $436-41-1,44-45$ & 379.0 & $\begin{array}{l}\text { Brown lami- } \\
\text { nated porcel- } \\
\text { lanite }\end{array}$ & $\begin{array}{l}86 \% \text { opal-CT } \\
14 \% \text { quartz }\end{array}$ & 4.093 & - & 1.69 & 2.29 & 26 & 1.95 & 2.5 & 4.9 & $\begin{array}{l}\text { Yellow and brown } \\
\text { zeolitic clay }\end{array}$ \\
\hline $436-42-1,7-10$ & 388.1 & $\begin{array}{l}\text { Brown lami- } \\
\text { nated chert }\end{array}$ & $\begin{array}{l}\text { quartz } \\
\text { tr. opal-CT }\end{array}$ & - & $<1$ & 2.43 & 2.58 & 6 & 2.49 & 3.1 & 7.7 & $\begin{array}{l}\text { Brown } \mathrm{Fe} \text {-and } \\
\text { Mn-clays }\end{array}$ \\
\hline $436-42-1$ a, 14-17 & 388.2 & $\begin{array}{l}\text { Red, orange, } \\
\text { and brown } \\
\text { chert }\end{array}$ & $\begin{array}{l}60 \% \text { opal-CT } \\
40 \% \text { quartz }\end{array}$ & 4.091 & $<1$ & 2.27 & 2.38 & 5 & 2.32 & - & - & $\begin{array}{l}\text { Brown Fe-and } \\
\text { Mn-clays }\end{array}$ \\
\hline $436-42 \cdot 1 \mathrm{~b}, 14-17$ & 388.2 & $\begin{array}{l}\text { Brown porcel- } \\
\text { lanite }\end{array}$ & $\begin{array}{l}78 \% \text { opal-CT } \\
22 \% \text { quartz }\end{array}$ & 4.096 & - & 1.57 & 2.32 & 32 & 1.89 & - & - & $\begin{array}{l}\text { Brown } \mathrm{Fe} \text {-and } \\
\text { Mn-clays }\end{array}$ \\
\hline $436-42-1,25-30$ & 388.3 & $\begin{array}{l}\text { Brown lami- } \\
\text { nated porcel- } \\
\text { lanite with } \\
\text { chert nodule }\end{array}$ & $\begin{array}{l}74 \% \text { opal-CT } \\
26 \% \text { quartz }\end{array}$ & 4.092 & - & 1.69 & 2.33 & 27 & 1.96 & 4.9 & 9.5 & $\begin{array}{l}\text { Brown Fe- and } \\
\text { Mn-clays }\end{array}$ \\
\hline
\end{tabular}

Sample 436-42-1, 25-30 cm, a brown, laminated porcellanite, contains the only bona fide incipient chert nodule in these siliceous rocks (Figure 3C). Bedding passes undisturbed through the gradational contact between the chert and porcellanite, implying that this nodule formed after compaction and initial silicification of the host claystone. Keene (1975, p. 436) describes a similar nodule from Site 304.

Light-brownish-white inclusions of quartzose porcellanite occur in some of the laminated brown cherts (Figure 3A; compare with Keene, 1975, p. 485, pl. 18, figs. 1 and 3 ). In some cases, bedding continues through these inclusions. Some inclusions are massive, more porous, and contain some pyrite. I support Keene's contention that these inclusions may form when silicification encloses small areas of higher porosity, thereby reducing the supply of silica.

\section{Breccias and Veins}

Only the two yellow cherts from Core 436-41 show brecciation and veining. In Sample 436-41-1, 42-43 cm (Figure 6A), a brecciated zone $6 \mathrm{~mm}$ wide contains fragments of chert geopetally arranged in clear chalcedony and microcrystalline quartz. Pieces of an orange lens split during brecciation are displaced about $2 \mathrm{~cm}$ in the fractured zone. The slight angular discordance between the top of the fill in the fracture and bedding in the host chert may indicate that some rotation accompanied fracturing (Figure 6B).

Crosscutting relationships define at least three generations of fractures and veins in these two samples. Clear, length-fast chalcedony growing perpendicular to the walls completely fills most of these fractures. In one instance chalcedony only partially fills a fracture, leaving a lens-shaped void.

In addition to Keene's work, earlier DSDP investigations report breccias and, more commonly, veins in cherts recovered from the Pacific basin that are much like those described above (for example, Pimm et al., 1971, pp. 1183 and 1216; Heath and Moberly, 1971, p. 1005; Lancelot, 1973, pp. 401-403). All these cherts come from relatively stable oceanic settings that tend to exclude tectonism as a cause for fracturing. I favor Keene's interpretation that these breccias and fractures are probably collapse features formed during the various stages of compaction and silicification of the original siliceous sediment. On land, similar features occur in bedded-chert sequences of various ages. Examples include the Monterey Shale, California (Bramlette, 1946); the Mishash Formation, Israel (Kolodny, 1969); and the Caballos Formation, Texas (Folk and McBride, 1976; McBride and Folk, 1977).

\section{Mineralogy}

Opal-CT and quartz are the two most abundant polymorphs of silica in the rocks studied. Opal-CT is mostly crypto-crystalline, although lepispheres (Wise and Kelts, 1972) occur in some voids. Fibrous, lengthfast chalcedony is common in veins and in radiolarian molds (Figure 7).

Relatively high $d(101)$ values (Table 1) demonstrate the poor ordering of opal-CT in these rocks. We drilled and recovered too short a section to test whether these values decreased with increasing depth of burial, as Murata and Nakata (1974) and Murata and Larson (1975) have reported for the Monterey Shale in California. At nearby sites, Keene (1976, p. 197) reports similar values which show no systematic ordering with increasing depth.

The low values of the crystallinity index of quartz in these rocks indicate extremely small crystallites (less than $100 \AA$ in the [1011] direction using the Scherer formula; Klug and Alexander, 1974, p. 656). In cherts from the Monterey Shale, I have observed quartz of low crystallinity replacing disordered opal-CT $(d[101]=4.07 \AA$ or greater), suggesting that in some cases opal-CT does not become completely ordered (i.e., $d[101]=4.04 \AA$ ) before being converted to quartz. Figure 8 illustrates a similar occurrence from Site 436. Perhaps other quartzose chert from this site also had opal-CT precursors.

I made no detailed chemical investigation in this study of the nonsilica components of cherts and porcellanites. 

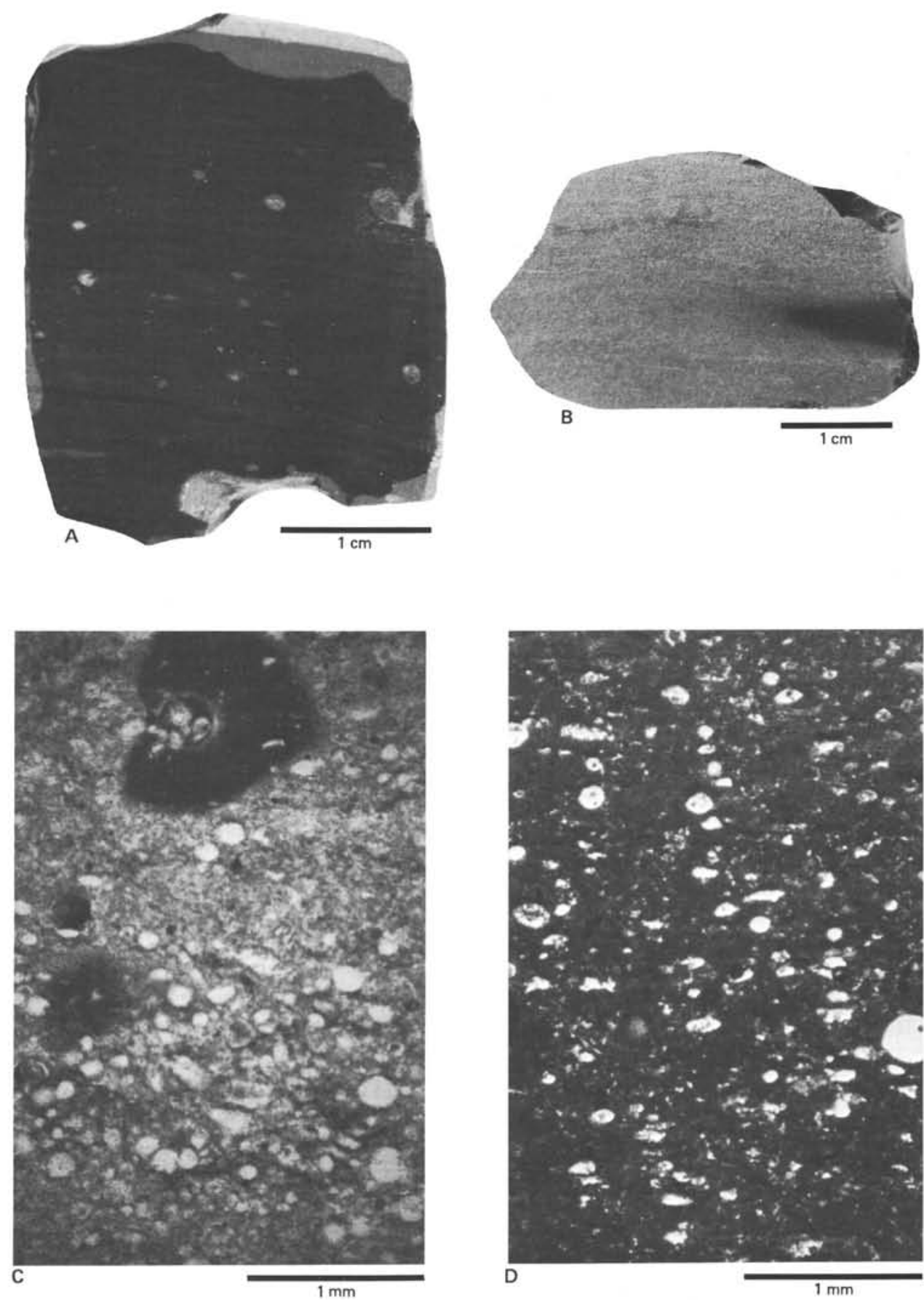

Figure 3. Laminated siliceous rocks, Site 436. A. Cut surface of brown, laminated, quartzose chert. Light-colored inclusions are porcellanite. Sample 436-42-1, 7-10 $\mathrm{cm}$. B. Photomicrograph of sample in (A), showing concentrations of reworked(?) radiolarians now replaced and filled with quartz. C. Cut surface of brown laminated porcellanite with dark-brown incipient chert nodule. Sample 436-42-1, 25-30 $\mathrm{cm}$. D. Photomicrograph of sample in (C), showing indistinct laminations comprising filled and replaced radiolarians. $B$ and $D$ are plane light.

Thin-section and XRD data, and analogy with similar siliceous rocks from the central Pacific (Pimm et al., 1971, pp. 1216 and 1217), indicate that cryptocrystalline opal-CT and (or) quartz compose much of the matrix of these cherts and porcellanites, with subordinate amounts of clays (mostly montmorillonite) and iron and manganese oxides. Small, reddish-brown spherules and rounded aggregates of amorphous iron oxide are common in both the silicified and unsilicified rocks and sediments from Site 436 (Cores 39-42). These particles are found 


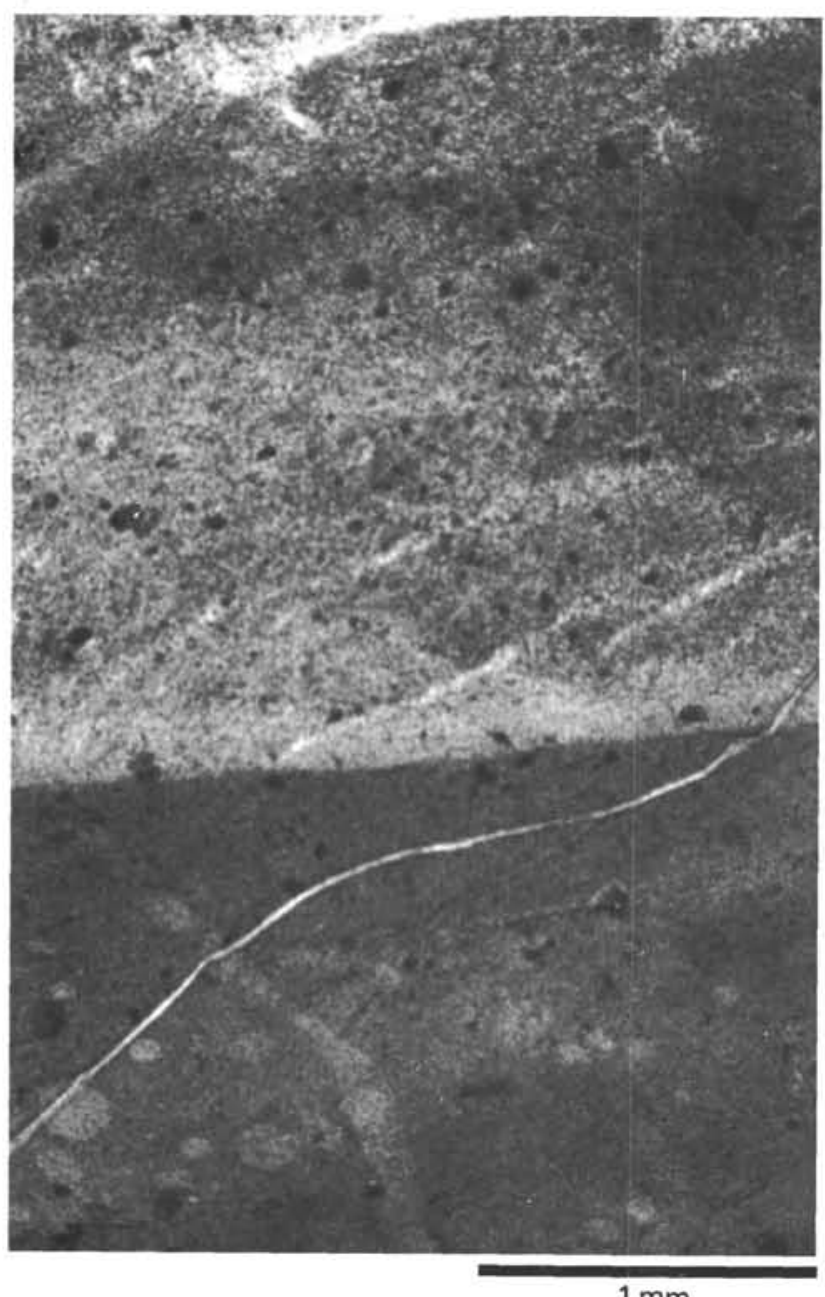

$1 \mathrm{~mm}$

Figure 4. Photomicrograph perpendicular to bedding, showing a sharp contact between quartzose chert and underlying clay-rich radiolarian chert, which may reflect mild reworking of the upper unit. Sample 436$41-1,42-44 \mathrm{~cm}$.

in comparable sediments from the Pacific basin (Pimm et al., 1971; von der Borch and Rex, 1970; von der Borch et al., 1971; Cronan et al., 1972), and similar aggregates occur in jasper beds in the Caballos Formation of Texas (McBride and Folk, 1977, p. 1267) and in cherts and associated red shales of the Franciscan complex of California (Davis, 1918; Bailey et al., 1964).

\section{Physical Properties}

Dry-bulk densities roughly correlate with the relative amounts of quartz and opal-CT in the samples studied, with a single notable exception (Table 1). Sample 436-41-1, 40-42 cm, a pale-brownish-white, faintly laminated porcellanite, has a dry-bulk density and porosity quite similar to those of opal-CT-bearing samples, although it is completely quartz (Figure 9). Texturally and mineralogically, this sample resembles the light-brownish-white inclusions of porcellanite in Sample 436-42-1, $7-10 \mathrm{~cm}$ (Figure $3 \mathrm{~A}$ ) and may have had a similar origin. It also resembles some of the quartzose porcellanites in

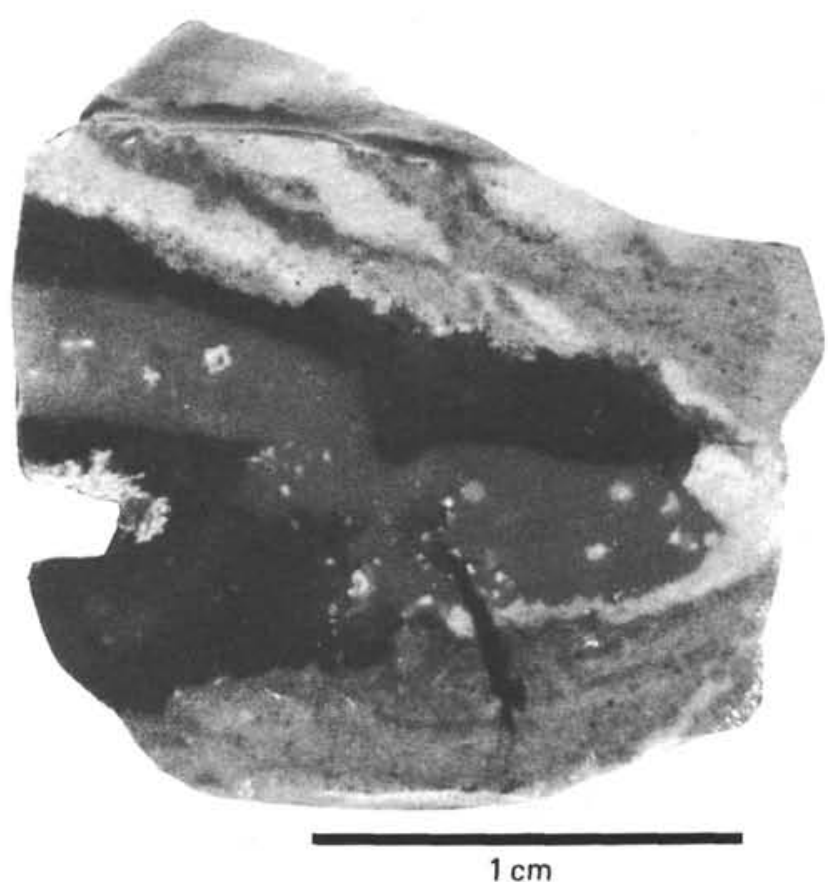

Figure 5. Orange and red lenses in chert associated with brown clay. Outer, lighter-colored areas of sample are composed of opal-CT; center, darker area is quartzose. Sample 436-42-1a, 14-17 cm.

the Monterey Shale, suggesting that is may have formed in rocks which were more clay-rich, sometime after formation of cherts within the same stratigraphic interval (Murata and Nakata, 1974; Murata and Larson, 1975). In either case, silicification of the surrounding sediment may have prevented more complete impregnation of this rock with silica, resulting in a porous, low-density, quartzose porcellanite.

In contrast to dry-bulk densities, sonic velocities do not vary systematically with silica mineralogy (Table 1 ). Using an average value of $2.72 \times 10^{5} \mathrm{~g} / \mathrm{cm}^{2}$-sec for the acoustic impedance of the immediately overlying unsilicified clays (Carson and Bruns, this volume), the reflections coefficients for the boundary between chertporcellanite and clay-claystone range from 0.29 to 0.65 . These high values are not surprising, because chert and porcellanite layers are strong seismic reflectors in the Pacific and Atlantic Oceans and in the Bering Sea (Ewing et al, 1966; Gartner, 1970; Larson, Moberly, et al., 1975; Saunders et al., 1973; Scholl and Creager, 1973; Hein et al., 1978).

\section{INTERPRETATION}

The cherts and porcellanites at Site 436 probably formed in much the same way as similar siliceous rocks from Sites 303, 304, and 307 in the North Pacific, as discussed by Keene (1975). Traditionally, biogenic and volcanic materials are cited as sources of silica for cherts and porcellanites (see summaries and references in Grunau, 1965; Garrison, 1974, pp. 368 and 369; Calvert, 1974, pp. 290-292). An additional source of silica may be the alteration of clay minerals (Keene and 

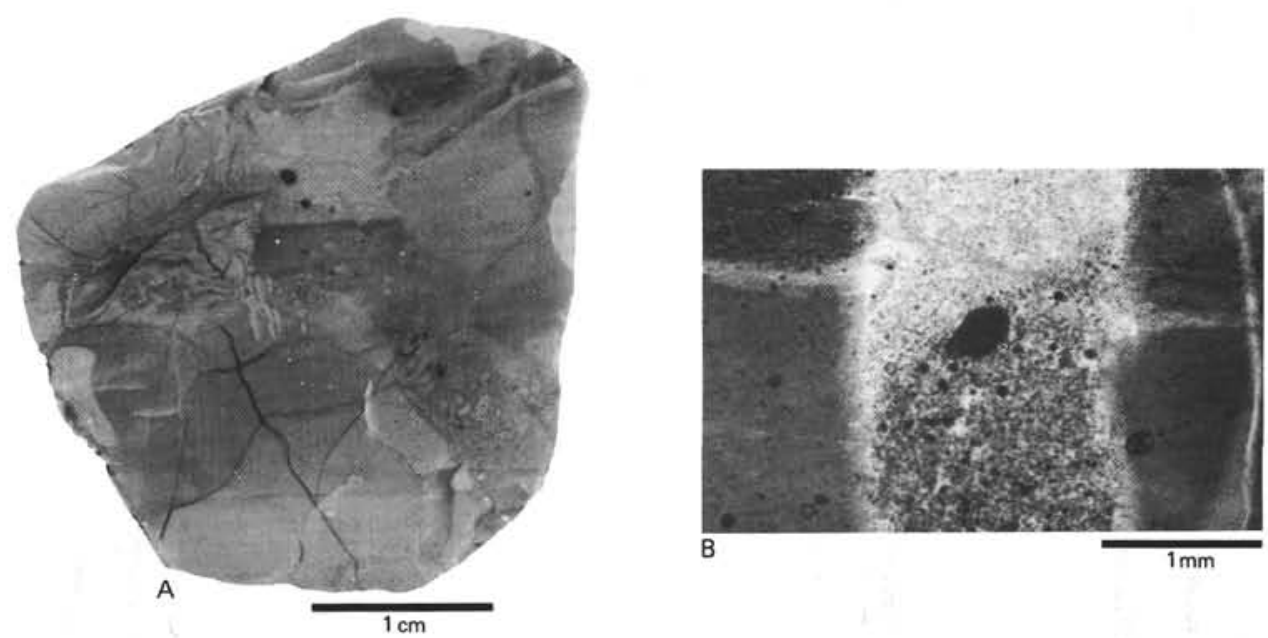

Figure 6. Brecciated yellow chert. (A) Cut surface showing major brecciated zone and displaced, geopetally arranged fragments. (B) Photomicrograph of the same sample, showing apparent slight angular discordance between fill in fracture (lighter zone) and faint bedding in the broken radiolarian chert (darker area flanking the fracture). Plane light. Sample 436-41-1, 42-44 cm.
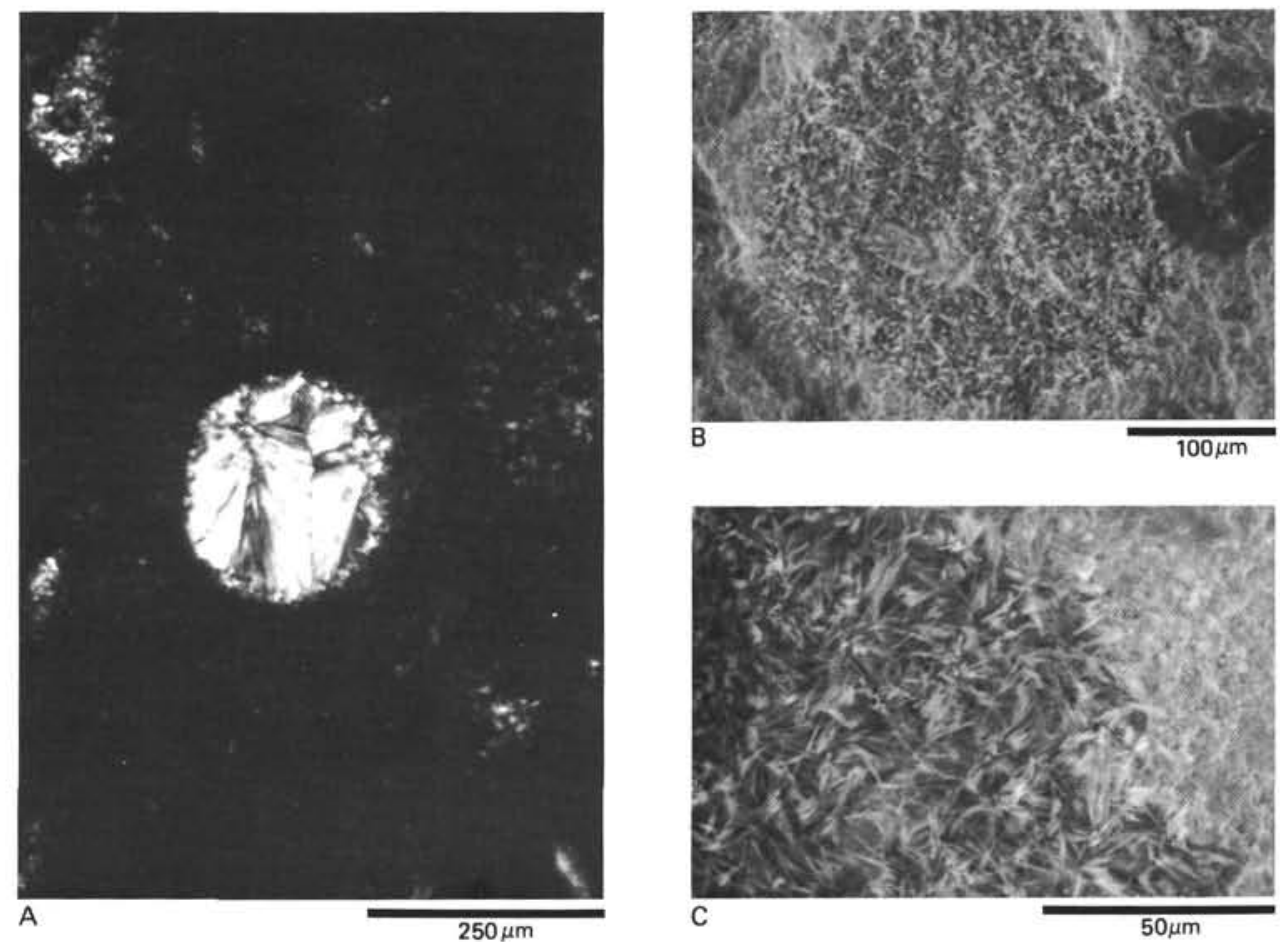

Figure 7. Morphology of fibrous, length-fast chalcedony filling radiolarian molds. (A) Photomicrograph, showing chalcedony-filled mold (crossed nicols). (B, C) SEM photographs of chalcedony-filled mold, showing individual fibers and needles of chalcedony. Sample 436-41-1, 44-45 cm.

Kastner, 1974). Numerous quartz- and chalcedonyfilled radiolarian molds in the cherts and porcellanites, and abundant partially dissolved tests of radiolarians (Figure 10) in the overlying pelagic clay at Site 436, indicate that significant amounts of silica came from the dissolution of biogenic debris. On the other hand, montmorillonite, the common clay mineral in the sediments associated with siliceous rocks at this site (Cores 39 to 42), may signal the former presence of volcanic glass (Arrhenius, 1963; Peterson and Griffin, 1964; Rex, 1967). Likewise, partially dissolved crystals of clinoptilolite (Figure 11) in these clays and in a yellow 

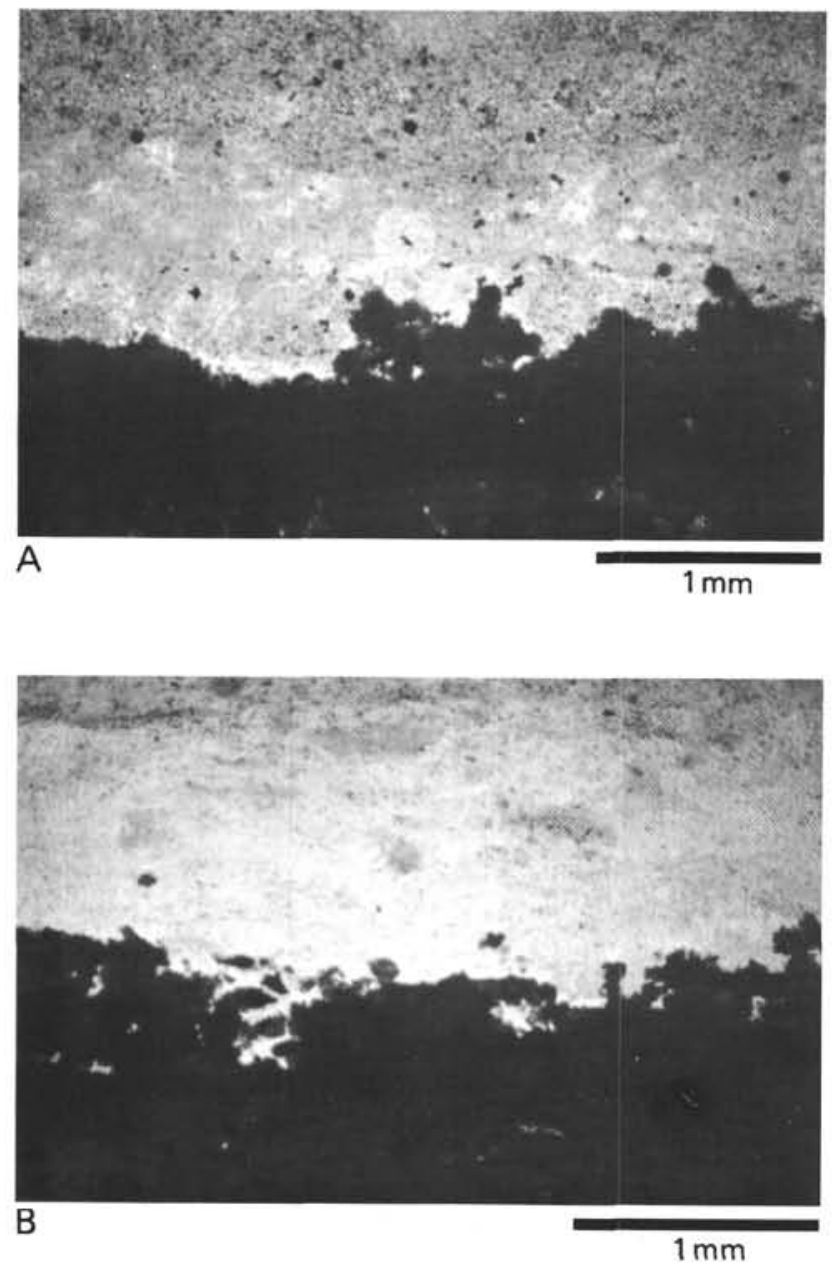

Figure 8. Photomicrographs of the boundary between opal-CT (dark) and microcrystalline quartz (light) in Sample 436-42-1a, 14-17 cm (A) and in a chert from the Miocene Monterey Shale, California (B) Note irregular boundary and remnant patches of opal-CT in quartz. d(101) spacings for opal-CT are (A) $4.091 \AA$ and $(B) 4.083 \AA$.

clay adjacent to yellow quartzose cherts (Core 41) may also suggest a volcanic source. A possible reaction for the formation of clinoptilolite is

1) Basaltic glass + silica (mainly biogenic) $\rightarrow$ clinoptilolite (Weaver, 1968; Berger and von Rad, 1972; Cook and Zemmels, 1972).

Alternatively, clinoptilolite may form in the absence of volcanic glass by the reactions

2) Phillipsite + biogenic silica + water $\rightarrow$ clinoptilolite (Boles and Wise, 1977; Boles, 1977)

or

3) Phillipsite + biogenic silica + smectite $\rightarrow$ clinoptilolite (Berger and von Rad, 1972; Couture, 1976).

Most likely, both volcanic and biogenic debris provided silica now incorporated in cherts and porcellanites at Site 436. Further work, using the oxygen-isotope composition of the silica phases, is necessary to provide more unequivocal evidence on the extent of the contribution from each source (see Henderson et al., 1971; Kastner, 1976, p. 517).

I found no clinoptilolite in the studied cherts and porcellanites, and only partially dissolved crystals in the associated pelagic clay. Either silicification preceded the formation of clinoptilolite, or diagenetic silica and clinoptilolite formed simultaneously in adjacent layers. As a third alternative, silicification may have succeeded complete dissolution of clinoptilolite in those layers that became silicified.

Unaltered biogenic silica (opal-A) is abundant in the 360 meters of Neogene radiolarian and diatomaceous deposits that overlie the Cretaceous cherts and porcellanites at this site. The exact age of the Cretaceous siliceous rocks is uncertain, but by analogy with similar rocks at Site 304 (Keene, 1975) they may be old as Cenomanian or Albian (90-100 m.y.; see also Sakai, this volume). If these rocks are the products of burial diagenesis, then the diagenetic quartz in them may have taken as much as 80 to $90 \mathrm{~m}$.y. to form. Opal-CT probably formed earlier, because quartz replaces opal-CT in some samples. Keene (1975) suggests that, except in areas of high geothermal gradients, the formation of chert and porcellanite may require 40 to $50 \mathrm{~m}$.y. Of course, similar cherts are found in comparable but younger sediments of the Pacific basin (Pimm et al., 1971 , p. 1213), so that these crude estimates are probably close to maximum values for the time it took chert to form at this site.

Besides time, temperature controls the transformation of biogenic silica to its diagenetic polymorphs (Ernst and Calvert, 1969; Mizutani, 1977; Kastner et al., 1977, and references therein). Langseth (this volume) calculates a linear geothermal gradient of $76^{\circ} \mathrm{C} / \mathrm{km}$ at Site 436 . Using this value, and assuming that $1.5^{\circ} \mathrm{C}$ is the temperature at the sea floor, the present temperature at the top of the Cretaceous cherts and porcellanites (sub-bottom depth $379 \mathrm{~m}$ ) is $30^{\circ} \mathrm{C}$. If diagenetic zones of silica keep pace with accumulating overburden mainly as a response to increased temperatures (Mizutani, 1977 , fig. 6), then $30^{\circ} \mathrm{C}$ represents the approximate temperature of conversion of biogenic to diagenetic silica. Moreover, both quartz and opal-CT compose the diagenetic silica at this site. If we assume that all quartz had an opal-CT precursor, then a lower temperature for the conversion of biogenic opal-A to opal-CT would be expected; $30^{\circ} \mathrm{C}$ would represent the temperature of formation of quartz from opal-CT. Of course, time and host lithology also control the path of transformation of biogenic silica to its diagenetic polymorphs (Lancelot, 1973; Keene, 1975; Kastner et al., 1977), so that $30^{\circ}$ is only a rough estimate of the temperature of conversion.

Keene (1975) indicates that the texture and composition of the host sediment control the site and method of formation of chert and porcellanite, replacement and impregnation of the original sediment with silica being the two most likely mechanisms. The preservation of fine laminations of orange, altered volcanogenic lenses and the abundant iron-oxide aggregates in the brown 

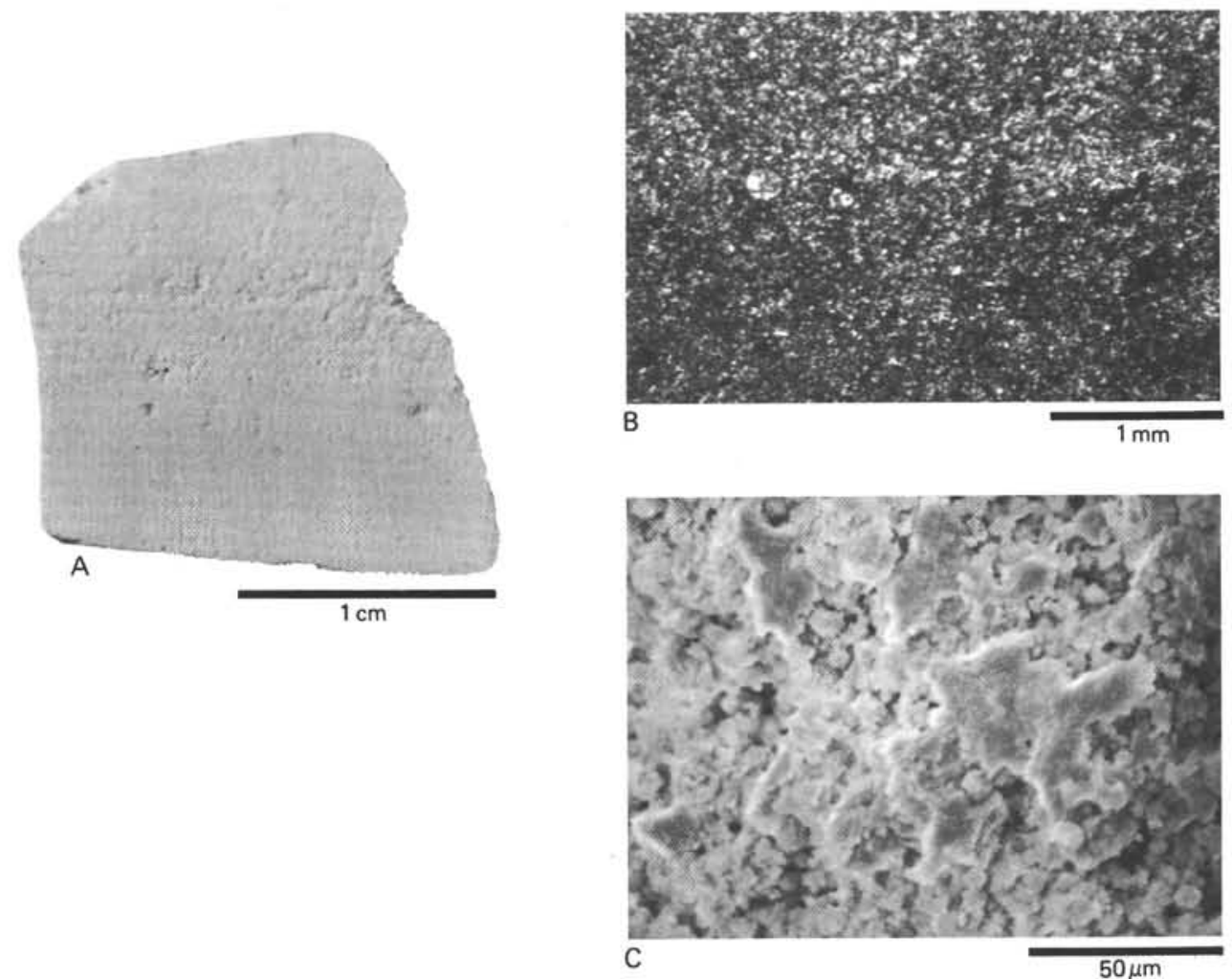

Figure 9. Pale-brownish-white, quartzose porcellanite. (A) Cut surface, showing faint horizontal laminations and porous surface texture. (B) Photomicrograph of same sample, showing microgranular texture (crossed nicols). (C) SEM photograph, showing coalescing patches of granular, poorly crystalline quartz. Sample $4365-41-1,40-42 \mathrm{~cm}$.

cherts and porcellanites at Site $\mathbf{4 3 6}$ argue for formation by impregnation of the associated brown clays with silica. The yellow cherts (Core 41$)$ probably formed in a similar fashion from yellow clays. These associated clays have high primary porosities (avg. 65\%, Carson and Bruns, this volume). Their silicification easily could have produced cherts and porcellanites without disruption of sedimentary structures.

Only two samples of chert at Site 436 show any evidence of possible reworking and redeposition (Figures $3 \mathrm{~B}$ and 4 ). Indeed, of the many reports of siliceous rocks from the Pacific basin, only Keene (1975, p. 438 , and pls. 3 and 28 ) describes structures in two calcareous porcellanites that may indicate reworking. Heath and Moberly (1971, p. 992) report a porcellaneous turbidite, but give no detailed description. In pelagic sediments deposited in rifted, slow-spreading areas such as the Mid-Atlantic Ridge, where frequent faulting produces significant relief, one might expect to find assemblages of sedimentary structures such as graded bedding, flute casts, and small-scale cross laminations indicative of redeposition (Garrison, 1974, pp. 385-388). On the other hand, in non-rifted or slightly rifted, rapidly spreading ridges such as the East Pacific Rise, pelagic sediments may show very little evidence of transport. Lancelot and Larson (1975) calculated a relatively high spreading rate (half rate about $4 \mathrm{~cm} / \mathrm{yr}$ ) from the $\mathrm{M}$-series magnetic anomalies near Sites 303 and 304 . The Cretaceous siliceous rocks at Site 436 probably formed in this second tectonic and sedimentary setting and may be significant analogues for onshore cherts such as those in the Franciscan complex of California.

\section{ACKNOWLEDGMENTS}

R. E. Garrison and J. C. Moore offered helpful suggestions for this work. Financial support came from National Science Foundation Grant (EAR76-22131) to R. E. Garrison. All are gratefully acknowledged.

\section{REFERENCES}

Arrhenius, G., 1963. Pelagic sediments. In Hill, M. N. (Ed.), The Sea (Vol. 3): New York (Interscience), 655-727.

Bailey, E. H., Irwin, W. P., and Jones, D. L., 1964. Franciscan and related rocks, and their significance in the geology of western California. Calif. Div. Min. Geol., Bull. 183.

Berger, W. H., and von Rad, U., 1972. Cretaceous and Cenozoic sediments from the Atlantic Ocean. In Hays, D. F., Pimm, A. C., et al., Init. Repts. DSDP, 14: Washington (U.S. Govt. Printing Office), 787-954.

Boles, J. R., 1977. Zeolites in deep-sea sediments. In Mumpton, F. A. (Ed.), Mineralogy and geology of natural 


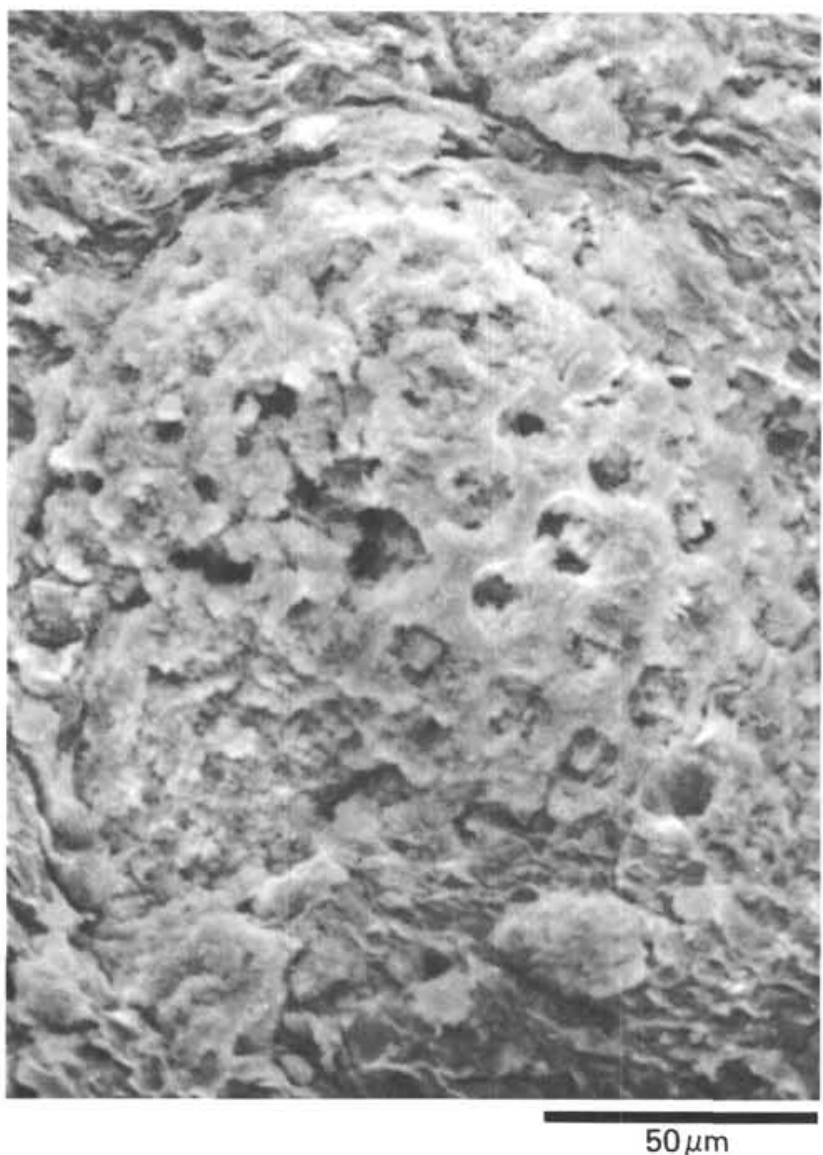

Figure 10. SEM photograph of partially dissolved test of radiolarian (opal-A) in zeolitic clay overlying chert. Sample 436-41-1, 27-29 cm.

zeolites: Mineral Soc. Am. Short Course Notes, 4, 137164.

Boles, J. R., and Wise, W. S., 1977. Nature and origin of deep-sea clinoptilolite. In Sand, L. B., and Mumpton, F. A. (Eds.), Natural Zeolites: Occurrence, Properties and Use: Elmsford, New York (Pergamon Press).

Böstrom, K., and Peterson, M. N. A., 1969. The origin of aluminum-poor ferromanganoan sediments in areas of high heat flow on the East Pacific Rise. Mar. Geol., 7, 427447.

Bramlette, M. N., 1946. The Monterey Formation of California and the origin of its siliceous rocks. U.S. Geol. Survey, Prof. Paper 212.

Calvert, S. E., 1974. Deposition and diagenesis of silica in marine sediments. In Hsü, K. J., and Jenkyns, H. C. (Eds.), Pelagic Sediments: On Land and Under the Sea (Vol. 1): Spec. Publ. Int. Assoc. Sedimentologists, 273299.

Cook, H. E., and Zemmels, I., 1972. X-ray mineralogy studies - Leg 9. In Hays, J. D., Init. Repts., DSDP, 9: Washington (U.S. Govt. Printing Office), 707-787.

Couture, R. A., 1976. Composition and origin of palygorskite-rich and montmorillonite-rich zeolite-containing sediment from the Pacific Ocean. Chem. Geol., 13, 113-130.

Cronan, D. S., van Andel, T. H., Heath, G. R., Dinkelman, M. G., Bennett, R. H., Bukry, D., Santiago, C., Kaneps, A., Rodolfo, K. S., and Yeats, R. S., 1972. Iron-rich basal sediments from the Eastern Equatorial Pacific: Leg 16, Deep Sea Drilling Project. Science, 75, 61-63.

Davis, E. F., 1918. The radiolarian cherts of the Franciscan group. Univ. Calif. Pub., Dept. Geol. Bull, 11, 235-432.

Ernst, W. G., and Calvert, S. E., 1969. An experimental study of the recrystallization of porcellanite and its bearing on the origin of some bedded cherts. Am. J. Sci., 267-A, 114-133.

Ewing, J., Worzel, J. L., Ewing, M., and Windisch, D., 1966. Age of Horizon A and the oldest Atlantic sediments. Science, 154, 1125-1132.

Folk, R. L., and McBride, E. F., 1976. The Caballos Novaculite revisited. Part I. Origin of novaculite members. J. Sediment. Petrol., 46, 659-669.

Garrison, R. E., 1974. Radiolarian cherts, pelagic limestones and igneous rocks in eugeosynclinal assemblages. In Hsü, K. J., and Jenkyns, H. C. (Eds.), Pelagic Sediments: On Land and Under the Sea (Vol 1): Spec. Pub. Int. Assoc. Sedimentologists, 367-399.

Gartner, S., 1970. Sea-floor spreading, carbonate dissolution level and the nature of Horizon A. Science, 169, 10771079.

Grunau, H. R., 1965. Radiolarian cherts and associated rocks in space and time. Eclog. Geol. Helv., 58, 157-208.

Heath, G. R., 1973. Cherts from the Eastern Pacific, Leg 16 Deep Sea Drilling Project. In van Andel, T. H., Heath, G. R., et al., Init. Repts. DSDP, 16: Washington (U.S. Govt. Printing Office), 609-613.

Heath, G. R., and Moberly, R. J., 1971. Cherts from the western Pacific, Leg 7, Deep Sea Drilling Project. In Winterer, E. L., Riedel, W. R., et al., Init. Repts. DSDP, 16: Washington (U.S. Govt. Printing Office), 991-1007.

Hein, J. R., Scholl, D. W., Barron, J. A., Jones, M. G., and Miller, J., 1978. Diagenesis of late Cenozoic diatomaceous deposits and formation of the Bottom Simulating Reflector in the Southern Bering Sea. Sedimentology, 25, 155-181.

Henderson, J. H., Jackson, M. L., Syers, J. K., Clayton, R. N., and Rex. R. W., 1971. Cristobalite authigenic origin in relation to montmorillonite and quartz origin in bentonites. Clays Clay Min., 19, 229-238.

Jones, J. B., and Segnit, E. R., 1971. The nature of opal. I. Nomenclature and constituent phases. J. Geol. Soc. Australia, 18, 57-68.

Kastner, M., 1976. Diagenesis of basal sediments and basalts of Sites 322 and 323, Leg 35, Bellinghausen Abyssal Plain. In Hollister, C. D., Craddock, C., et al., Init. Repts. DSDP, 35: Washington (U.S. Govt. Printing Office), 513-527.

Kastner, M., Keene, J. B., and Gieskes, J. M., 1977. Diagenesis of siliceous oozes. I. Chemical controls on the rate of opal-A diagenesis - an experimental study. Geochim. Cosmochim. Acta, 41, 1041-1059.

Keene, J. B., 1975. Cherts and porcellanites from the North Pacific, DSDP Leg 32. In Larson, R. L., Moberly, R. J., et al., Init. Repts. DSDP, 32: Washington (U.S. Govt. Printing Office), 429-507.

1976. Petrography of biogenic and authigenic silica from the Pacific basin. Ph.D. thesis, Scripps Inst. Oceanogr., San Diego.

Keene, J. B., and Kastner, M., 1974. Clays and formation of deep-sea chert. Nature, 249, 754-755.

Klug, H. P., and Alexander, L. F., 1974. X-Ray Diffraction Procedures for Polycrystalline and Amorphous Materials (2nd ed.): New York (Wiley).

Kolodny, Y., 1969. Petrology of siliceous rocks in the Mishash Formation (Negev, Israel). J. Sediment. Petrol., 39, 166-175. 

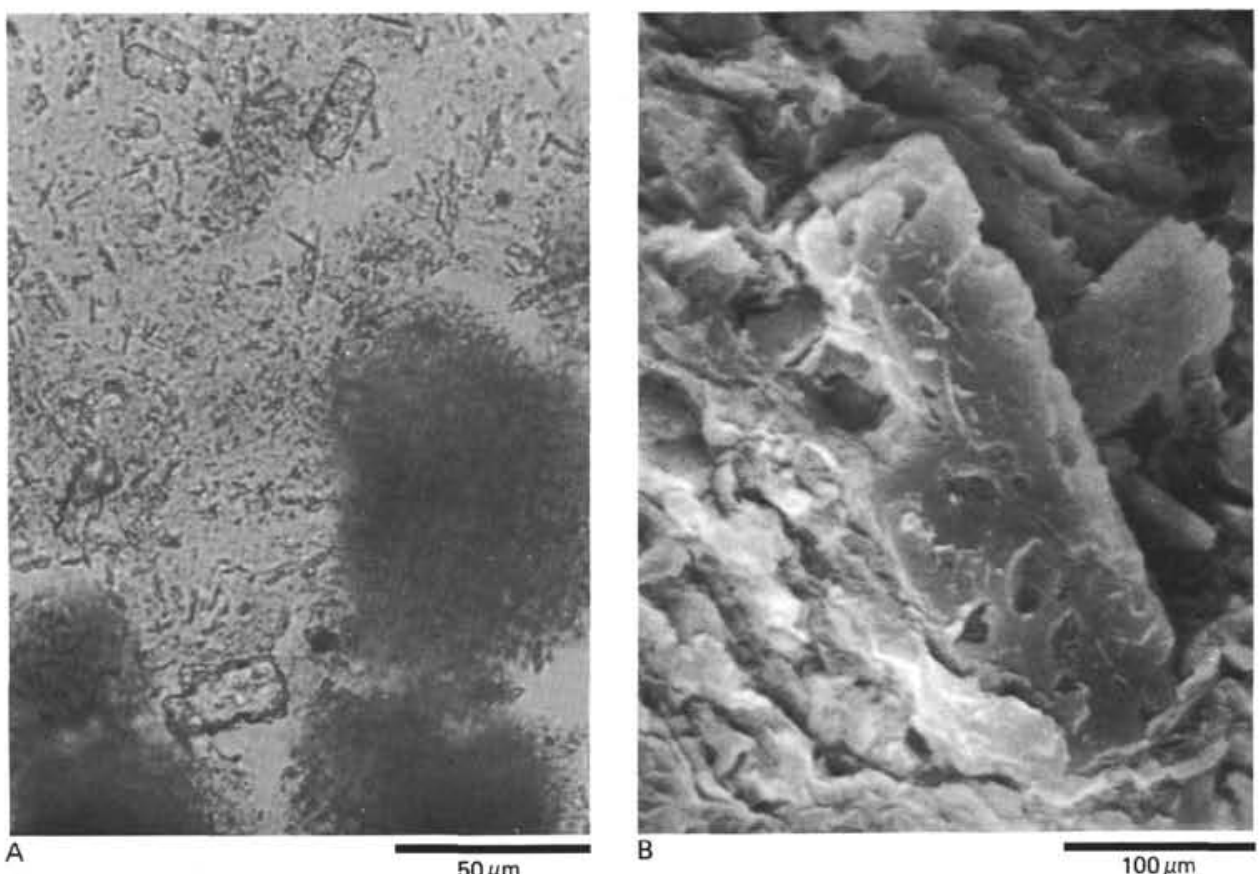

Figure 11. Clinoptilolite crystals in yellow clay associated with yellow chert. (A) Smear slide, showing abundant lath-shaped, partially dissolved crystals of clinoptilolite (plane light). (B) SEM photograph, showing pitted and dissolved prismatic crystal of clinoptilolite in clay above chert. Sample 436-41-1, 27-29 cm.

Lancelot, Y., 1973. Chert and silica diagenesis in sediments from the central Pacific. In Winterer, E. L., Ewing, J. I., et al., Init. Repts. DSDP, 17: Washington (U.S. Govt. Printing Office), 45-73.

Lancelot, Y., and Larson, R. L., 1975. Sedimentary and tectonic evolution of the northwestern Pacific. In Larson, R. L., Moberly, R. J., et al., Init. Repts. DSDP, 32: Washington (U.S. Govt. Printing Office), 925-939.

Larson, R. L., and Moberly, R. J., 1975. Site 304: Japanese magnetic lineatons. In Larson, R. L., Moberly, R. J., et al., Init. Repts. DSDP, 32: Washington (U.S. Govt. Printing Office), pp. 45-73.

Larson, R. L., Moberly, R. J., et al., 1975. Init. Repts. DSDP, 32: Washington (U.S. Govt. Printing Office).

McBride, E. F., and Folk, R. L., 1977. The Caballos Novaculite revisited: Part II, Chert and shale members and synthesis. J. Sediment. Petrol., 47, 1261-1286.

Mizutani, S., 1977, Progressive ordering of cristobalitic silica in the early stage of diagenesis. Contr. Mineral. Petrol., 61, 129-140.

Murata, K. J., and Larson, R. R., 1975. Diagenesis of Miocene siliceous shales, Temblor Range, California. J. Res. U.S. Geol. Survey, 3, 553-566.

Murata, K. J., and Nakata, J. K., 1974. Cristobalitic stage in the diagenesis of diatomaceous shale. Science, 184, 567568.

Murata, K. J., and Norman, M. B., II, 1976. An index of crystallinity for quartz. Am. J. Sci., 276, 1120-1130.

Peterson, M. N. A., and Griffin, J. J., 1964. Volcanism and clay minerals in the southeastern Pacific. J. Marine Res., $22,13-21$.

Pimm, A. C., Garrison, R. E., and Boyce, R. E., 1971. Sedimentology synthesis: lithology, chemistry and physical properties of sediments in the northwestern Pacific Ocean. In Fischer, A. G., Heezen, B. C., et al., Init. Repts. DSDP, 6: Washington (U.S. Govt. Printing Office), 1131-1252.
Rex, R. W., 1967. Authigenic silicates formed from basaltic glass by more than 60 million years' contact with sea water, Sylvania Guyot, Marshall Islands. Clays Clay Min., 15, 195-203.

Robertson, A. H. F., and Hudson, J. D., 1974. Pelagic sediments in the Cretaceous and Tertiary history of the Troodos Massif, Cyprus. In Hsü, K. J., and Jenkyns, H. C. (Eds.), Pelagic Sediments: On Land and Under the Sea (Vol. 1): Spec. Pub. Int. Assoc. Sedimentologists, 403436.

Saunders, J. B., Edgar, N. T., Donnelly, T. W., and Hay, W. W., 1973. Cruise synthesis. In Edgar, N. T., Saunders, J. B., et al., Init. Repts. DSDP, 15: Washington (U.S. Govt. Printing Office), 1077-1112.

Scholl, D. W., and Creager, J. S., 1973. Geologic synthesis of Leg 19 (DSDP) results: Far North Pacific, Aleutian Ridge and Bering Sea. In Creager, J. S., Scholl, D. W., et al., Init. Repts. DSDP, 19: Washington (U.S. Govt. Printing Office), 897-913.

von der Borch, C. C., Nesteroff, W. D., and Galehouse, J., 1971. Iron-rich sediments cored during Leg 8 of the Deep Sea Drilling Project. In Tracy, J. I., Jr., Sutton, G. H., et al., Init. Repts. DSDP, 8: Washington (U.S. Govt. Printing Office), 829-835.

von der Borch, C. C., and Rex, R. W., 1970. Amorphous iron oxide precipitates in sediments cored during Leg 5, Deep Sea Drilling Project. In McManus, D. A., Burns, R. E., et al., Init. Repts. DSDP, 5: Washington (U.S. Govt. Printing Office), 541-544.

Weaver, C. E., 1968. Mineral facies in the Tertiary continental shelf and Blake Plateau. Southeastern Geology, 9, 57-63.

Wise, S. W., and Kelts, K. B., 1972. Inferred diagenetic history of a weakly silicified deep sea chaik. Trans. Gulf Coast Assoc. Geol. Soc., 222, 177-203. 